Vol.45, n. 3 : pp. 375-384, September 2002 ISSN 1516-8913 Printed in Brazil

\title{
Photosynthesis, Growth and Development of Tabebuia avellanedae Lor. ex Griseb. (Bignoniaceae) in Flooded Soil
}

\author{
Viviane M. Davanso ${ }^{1 *}$; Luiz A. de Souza ${ }^{1}$; Moacyr E. Medri ${ }^{2}$; José A. Pimenta ${ }^{2}$ and \\ Edmilson Bianchini ${ }^{2}$ \\ ${ }^{I}$ Universidade Estadual de Maringá; DBI; NUPELIA; Curso de Pós-Graduação em Ecologia de Ambientes Aquáticos \\ Continentais; Av. Colombo, 5790; 87020-900; Maringá - PR - Brazil. ${ }^{2}$ Departamento de Biologia Animal e Vegetal; \\ Centro de Ciências Biológicas; Universidade Estadual de Londrina; pimenta@uel.br; moacyrmedri@uel.br; \\ POB 6001; 86051-970; Londrina - PR - Brazil
}

\begin{abstract}
Morphological, anatomical and ecophysiological modifications caused by flooding in the growth and development of Tabebuia avellanedae Lor. ex Griseb. (Bignoniaceae) were studied and correlated with tolerance to the excess of water in the soil. Three-month-old plants, grown in a greenhouse, underwent a period of 56 days of flooding and a postflooding period. Photosynthesis rate and growth decreased in $\mathrm{T}$. avellanedae when flooding duration increased. Though not much tolerant, plant adapted itself to short flooding periods. This relative tolerance was probably due to the capacity of $\mathrm{T}$. avellanedae in developing structures which lessened flooding effects and promoted internal diffusion of oxygen from the aerial part to the roots, such as stem fissures, superficial roots and hypertrophied lenticels in the roots. As there was no great variation in the internal anatomy of T. avellanedae leaves and roots, metabolic alterations might have helped in the survival of the species during flooding.
\end{abstract}

Key words: Inundation, oxygen deprivation, ecological anatomy, Tabebuia avellaneadae

\section{INTRODUCTION}

Riparian vegetation is fundamentally important in diminishing erosion that silts up the river channels, improving water quality (Lima, 1989) and providing food and shelter to land and water fauna (Marinho Filho and Reis, 1989). The study on the development of woody species in situations of oxygen deficiency in soils, one of the chief consequences in flooding, is indispensable when the preservation or reconstruction of riparian vegetation is dealt with mistakes in reforestation may thus be lessened (Medri and Correa, 1985).

Research on plant strategies on tolerance to flooding may be interpreted through metabolic (Crawford, 1978) and morph anatomic (Armstrong, 1979) changes. It is now evident that tolerance is due to close links between structural and metabolic characteristics associated with reproductive cycles and strategies (Blom et al., 1994).

Flooding causes reduction in photosynthesis rates and stomata conductance (Dreyer et al., 1991; Pimenta, 1998). The closing of stomata, and thus the reduction of transpiration and the maintenance of water potential in leaves, may inhibit desiccation. It may also cause a diminishing in $\mathrm{CO} 2$ assimilation with decrease in plant growth rate during flooding (Ruiz-Sánches et al., 1996). Decrease in biomass

\footnotetext{
${ }^{*}$ Author for correspondence
} 
accumulation, lengthening of plants due to flooding (Kolb et al., 1998; Medri et al., 1998), epinasty, chlorosis (Pimenta et al., 1994), early senescence (Marques et al., 1996) and abscission of leaves (Clemens et al., 1978; Yamamoto and Kozlowski, 1987) have been frequently recorded. Flooded plants may develop hypertrophied lenticels (Marques et al., 1996; Colli, 1998; Kolb et al., 1998; Medri et al., 1998), surperficial and adventitious roots (Pimenta et al., 1994; Lobo and Joly, 1995) and aerenchyma in stems and roots (Davanso-Fabro et al., 1998; Kolb et al., 1998), improving gaseous exchange between the plant and the atmosphere (Armstrong, 1978).

Tabebuia avellanedae Lor. ex Grseb. (Bignoniaceae), popularly known as "ipê-roxo" in Brazil, has been chosen for this research. Little is known on the species with regard to the ecological aspects of its development, in spite of its wide distribution and importance in many habitats. Species occurs from Maranhão (North state) to the southern region of Brazil and is extremely frequent in the states of Mato Grosso and São Paulo. It occupies the upper canopy of the semi-deciduous forest of the Paraná River basin where it grows with relative abundance. Because of its great durability, the wood is used for furniture and in house building (Lorenzi, 1992). According to Reitz et al. (1978), Tabebuia avellanedae is a very important species for the reforestation of degraded areas: plants are resistant in replantations, devel op well in the open field and when exposed to the sunshine produce a great number of winged fertile seeds.

The present experiment was a contribution towards a better knowledge of strategies using by tropical species to adaptated at inundation. It might als o help in projects for the recovery of riparian vegetation and attempts to answer the following questions:

- Did hypoxia affect the photosynthesis rate in Tabebuia avellanedae?

- What were the morphological, anatomical and ecophysiological changes caus ed by flooding and post-flooding in Tabebuia avellanedae?

- What were the consequences of flooding on the growth and development of the species?

\section{MATERIALS AND METHODS}

Seeds of Tabebuia avellanedae were removed from fruit, washed, dried and left to germinate in recipients with $700 \mathrm{~g}$ of wet substratum consisting of $80 \%$ soil and $20 \%$ mixture of grated grass, lime and coffee powder. Germination occurred in a nursery. After two months, some plants, selected as to their uniformity in size and development, an $\mathrm{d}$ the substratum were placed in 4-L plastic pots with soil and sand in a 3:1 proportion. Experiment started a month after plant acclimatization. Forty plants were divided into 5 groups to measure photosynthesis rate, conductance and $\mathrm{CO}_{2}$ internal concentration: field capacity and plants flooded for 2, 7, 17 or 40 days. Measurements were undertaken in one of one of the leaflets of the plant's totally expanded leaf. Photosynthesis portable system LI-6200 and $\mathrm{CO}_{2}$ LI-6250 analyzer were used. During measurements average radiation on leaves was $1575.1 \mu \mathrm{molm}^{-2} \mathrm{~s}^{-1}$ and their average temperature was $25,6^{\circ} \mathrm{C}$.

On the first day of the experiment the length of the aerial part and of the main root, number of leaves, leaf area and stem's diameter at $2 \mathrm{~cm}$ from soil (sliding ruler) were evaluated in 16 plants for growth and development analysis. To determine leaf area, two correcting values, 0.726 and 0.376 , were determined for simple and compound leaves respectively from previous length measurements, width and area of 60 leaves by the gravimetric method. Plants were then divided into leaves, stems and roots and placed in a buffer at $60^{\circ} \mathrm{C}$ during 72 hours to obtain constant dry weight.

Another 80 plants were divided into three groups: $\mathrm{fc}$ (field capacity); fd (plants in water at $2 \mathrm{~cm}$ from soil); fdfc (return of flooded plants to field capacity on the $28^{\text {th }}$ day). Similar evaluations were undertaken with 16 plants of each group after 28 and 56 days. New leaves and number of leaves lost by abscission were taken into account. Relative g rowth rate (RGR) for each part of the plant and for the whole plant was calculated by formula $\mathrm{RGR}=(\mathrm{ln}$ WDf - ln WDi) / d, where WDf is final weight of dry matter; WDi is the initial weight of dry matter and $d$ the number of days of treatment. Net assimilatory rate (NAR) was calculated by formula $\mathrm{NAR}=((\mathrm{WDf}-\mathrm{WDi}) / \mathrm{LAf}-\mathrm{LAi})) \times((\ln \mathrm{LAf}-\ln$ $\mathrm{LAi} /$ 56), where LAf is the final leaf area and LAi is the initial leaf area. Weekly follow up was undertaken for possible formation of stem fissures, hypertrophied lenticels, diageotropic roots and intumescence of stems and roots.

At the end of the experiment the comparative anatomy of $T$. avellanedae was analyzed from remaining laminas. $1-\mathrm{cm}$ segments were collected close to secondary roots of five control plants and of diageotropic roots of five flooded plants. In the case 
of leaflets, segments of five control plants and from five flooded ones from central region of the leaflet lamina of totally expanded leaves and formed during the experiment period were collected. Se gments were fixed in formol, acetic acid and alcohol (F.A.A. 70\%), dehydrated, diaphanized and placed in paraplast. Blocks were sectioned transversally at a thickness of $13 \mu \mathrm{m}$. Cuts were colored in basic blue and mounted on Canadian balsam. Laminas were analyzed by optic microscope for parameters: percentage of intercellular spaces of the roots' cortical parenchyma and of the leaflets' lacunal parenchyma (gravimetric method); diameter of cells of cortical parenchyma and of the tracheal elements of the roots' xylem and of the cells of the leaflets' adaxial and abaxial epidermis; thickness of roots' cortical parenchyma; thickness of leaflet and of the lacunal and palisade parenchyma. All microscopic measurements were made with micrometer ocular. Statistical analysis was based on variance analysis (ANOVA). LSD was determined by Tukey's test at $\mathrm{P} \leq 0.05$. Percentage data were transformed in arc sine of proportion root before being statistically analyzed.

\section{RESULTS}

After 7 days flooding caused reduction of photosynthesis rate in T. avellanedae. However, there was no significant rate difference among plants with 7, 17 and 40 days flooding (Fig. 1A). Stomata conductance diminished proportionately to an increase in hypoxia period (Fig. 1B). In spite of reduction in stomata conductance, internal concentration of $\mathrm{CO}_{2}$ didn't show any decreasing trend with an increase of flood period (Fig. 1C).

Flooding reduced leaf's RGR by approximately $30 \%$ and root's RGR by approximately $40 \%$. After re-aeration, growth of root and of the whole plant were recovered. NAR of flooded $T$. avellanedae was reduced to about $32 \%$ with recovery after re aeration (Table 1).
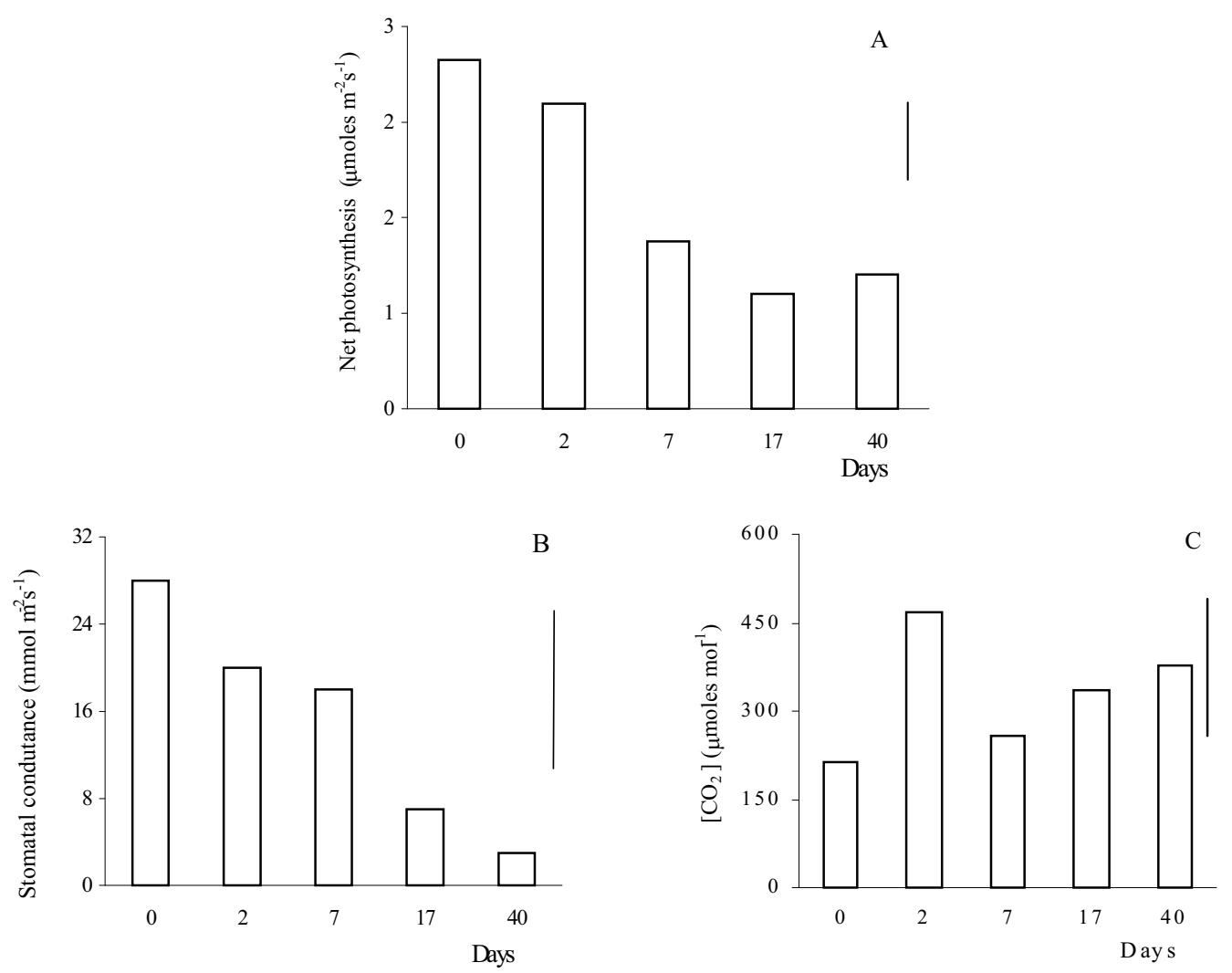

Figure 1 - Net photosynthesis (A), stomatal conductance (B) and internal concentration of $\mathrm{CO}_{2}(\mathrm{C})$ in $T$. avellanedae in field capacity (0) and flooded for 2, 7, 17 and 40 days. Vertical bar represents LSD by Tukey's test $(\mathrm{P} \leq 0.05 ; \mathrm{n}=8)$. 
Table 1 - Relative Growth Rate (RGR) and Net Assimilatory Rate (NAR) in T. avellanedae in field capacity (fc), flooded for 56 days (fd) and flooded for 28 days followed by 28 days of re-aeration (fdfc).

\begin{tabular}{cccccc}
\hline & \multicolumn{4}{c}{ RGR $\left(\mathrm{mg} \mathrm{g}^{-1} \mathrm{~d}^{-1}\right)$} & NAR $\left(\mathrm{mg} \mathrm{dm}^{-2} \mathrm{~d}^{-1}\right)$ \\
Treatment & Leaf & Stem & Root & Plant & Plant \\
\hline fc-56 & $0.021 \mathrm{a}$ & $0.018 \mathrm{a}$ & $0.029 \mathrm{a}$ & $0.024 \mathrm{a}$ & $0.025 \mathrm{a}$ \\
fd-56 & $0.015 \mathrm{~b}$ & $0.020 \mathrm{a}$ & $0.017 \mathrm{c}$ & $0.017 \mathrm{c}$ & $0.017 \mathrm{~b}$ \\
fdfc & $0.013 \mathrm{c}$ & $0.019 \mathrm{a}$ & $0.026 \mathrm{~b}$ & $0.019 \mathrm{~b}$ & $0.022 \mathrm{a}$
\end{tabular}

* Means separation within columns by Tukey's test $(\mathrm{P} \leq 0.05 ; \mathrm{n}=16)$.

Table 2 - Length Increase of aerial part and of root in T. avellanedae in field capacity (fc), flooded for 28 and 56 days (fd) and flooded for 28 days followed by 28 days of re-aeration (fdfc).

\begin{tabular}{llc} 
& \multicolumn{2}{c}{ Length increase $(\mathrm{cm})$} \\
Treatment & Shoot & Root \\
\hline fc-28 & $3.53 \mathrm{a}$ & $6.13 \mathrm{a}$ \\
$\mathrm{fd}-28$ & $3.28 \mathrm{a}$ & $0.31 \mathrm{~b}$ \\
$\mathrm{fc}-56$ & $4.88 \mathrm{a}$ & $9.56 \mathrm{a}$ \\
$\mathrm{fd}-56$ & $3.69 \mathrm{a}$ & $0.00 \mathrm{c}$ \\
fdfc & $3.34 \mathrm{a}$ & $1.81 \mathrm{~b}$ \\
\hline
\end{tabular}

* Means separation within columns by Tukey's test $(\mathrm{P} \leq 0.05 ; \mathrm{n}=16)$.
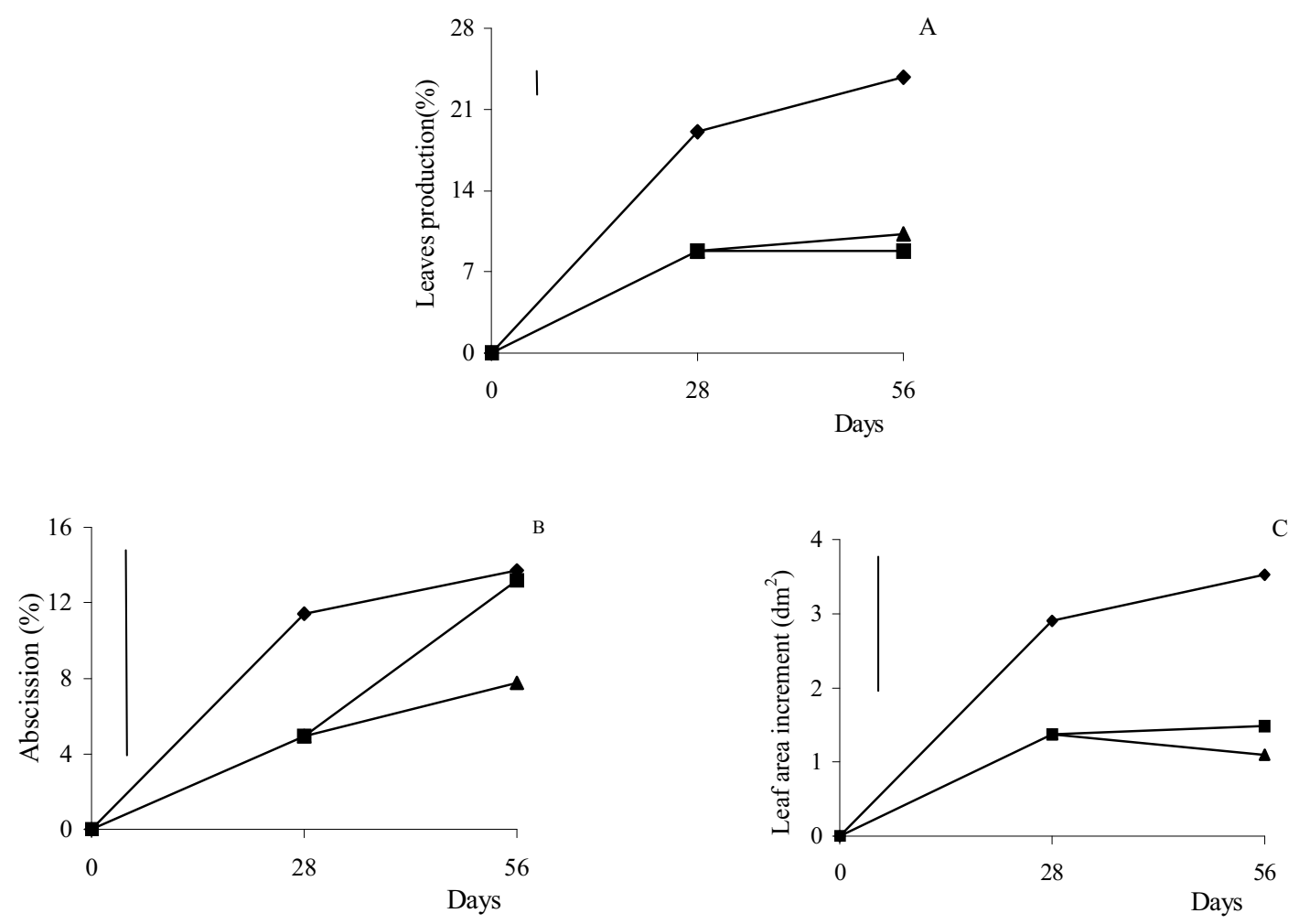

Figure 2 - Production (A) and abscission (B) of leaves and increase in leaf area (C ) in T. avellanedae in field capacity ( ), flooded for 28 and 56 days $(\boldsymbol{\square})$ and flooded for 28 days followed by 28 days of re-aeration $(\boldsymbol{A})$. Vertical bars represent LSD by Tukey's test $(\mathrm{P} \leq 0.05 ; \mathrm{n}=16)$. 
Growth in height of shoot was not affected (Table 2). After 28 and 56 days of experiment, there was a decrease in roots length of flooded plants. Recovery occurred after re-aeration.

Production of new leaves was smaller in flooded plants and without significant recovery after re aeration period (Fig. 2A). There was no difference in abscission of leaves between treatments (Fig. 2B). Flooding caused a reduction in le af area of $T$. avellanedae without any sign of recovery in re aeration of plants (Fig. 2C).

During the first 28 days of the experiment, flooding stimulated an increase in the stem's diameter (Fig. 3).

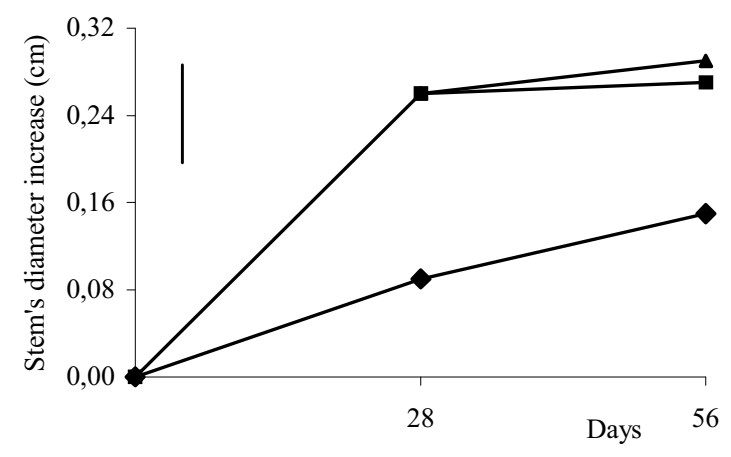

Figure 3 - Stem's diameter increase in $T$. avellanedae in field capacity $(\diamond)$, flooded for 28 and 56 days $(\boldsymbol{\square})$ and flooded for 28 days followed by 28 days of re-aeration (A). Vertical bar represents LSD by Tukey's test $(\mathrm{P} \leq 0.05$; $\mathrm{n}=16$ ).

From the second week, stem fissures started to develop in the flooded plants of T. avellanedae, and the sponge tissue of stems were exposed (Fig. 4). Flooding stimulated intumescence and the formation of hypertrophied lenticels in the roots of many plants, with exposure of sponge tissue (Fig. 4). At the end of the experiment, system of flooded plants' roots were less branched than those of controls. Traces of necrosis were also present (Fig.4).

From the $20^{\text {th }}$ day, the formation of diageotropic roots at the water surface was registered in flooded plants. They were much branched and of a whitish color (Fig. 5).

Taking into consideration all parameters evaluated in the internal anatomy of $T$. avellanedae, the only one to show a significant variation was that of the diameter of the leaflets' lower epidermis cells (Table 3). When similar regions of secondary roots of plants in field capacity and of diageotropic roots of flooded plants were analyzed, a higher number of absorbent hairs were found in the latter (Fig. 6).
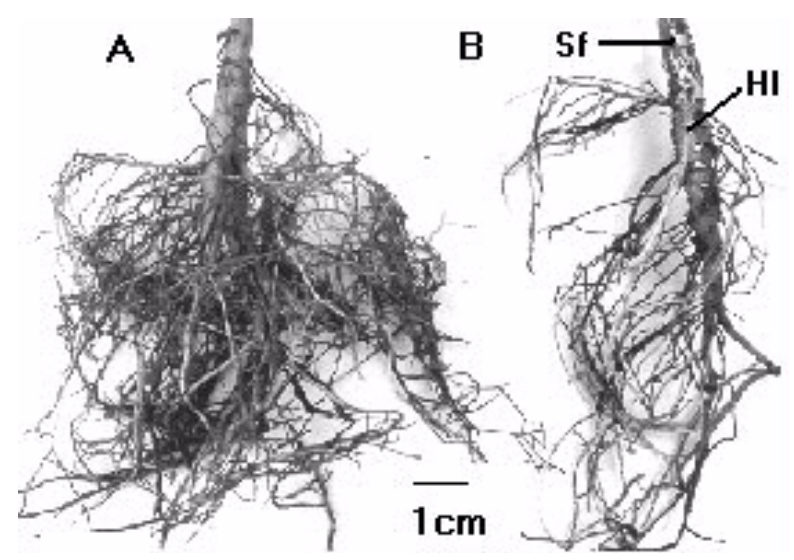

Figure 4 - T. avellanedae plants in field capacity (A) and flooded for 56 days (B). $\mathrm{Sf}=$ stem fissures; $\mathrm{Hl}=$ hypertrophied lenticels.

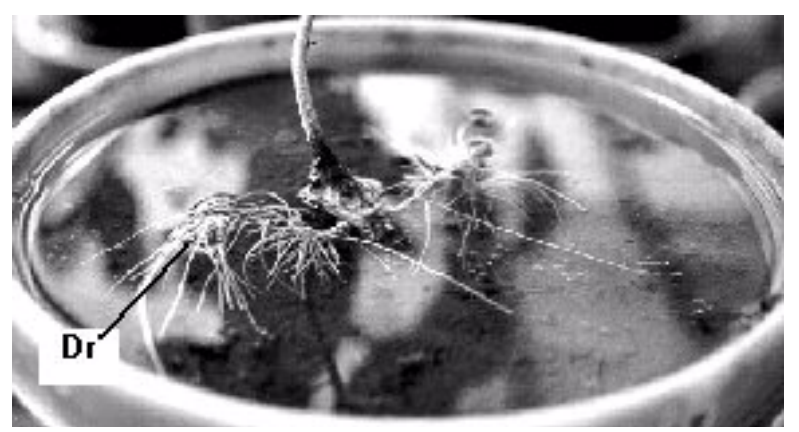

Figure 5 - Tabebuia avellanedae flooded for 56 days. Dr= diageotropic roots.

\section{DISCUSSION AND CONCLUSION}

A decrease in photosynthesis rate of T. avellanedae in proportion to the duration of flooding suggested that the species might be impaired in its development if exposed to long flood period. Decrease in photosynthesis had already been registered in Campomanesia xanthocarpa in flooding soil (Pimenta, 1998). Fall in photosynthesis in $T$. avellanedae could be related to closing of stomata, since stomata conductance tended to be lower in proportion to the increase of the inundation period. Many authors have suggested that stomata closing could be a response to fall in water potential due to decrease of 
absorption by roots and consequently dehydration of leaf was prevented (Ruiz-Sánches et al., 1996). However, in some cases, Quercus rubra, for example (Dreyer et al., 1991), sto mata closing occurred even when water potential was maintained. This fact suggested that other factors would be contributing towards the reduction of stomata conductance. These might be low soil oxygen concentration (Ruiz-Sánches et al., 1996) and the accumulation of ABA in leaves during hypoxia, which acted on the guard cells (Zhang and Davies, 1987).
The fact that in $T$. avellanedae internal concentration of $\mathrm{CO}_{2}$ did not decrease in spite of a reduction in stomata conductance suggested that other factors besides the closing of stomata also could be causing photosynthesis reduction. Dreyer et al., (1991) and Pimenta (1998) reported decrease of internal concentration of $\mathrm{CO}_{2}$ and suggested that photosynthesis limitation could be sometimes attributed to the cl osing of stomata.

Table 3 - Comparative anatomy of leaflet, secondary and diageotropic root in T. avellanedae in field capacity (fc) and flooded for 56 days (fd). $\mathrm{Sr}=$ secondary root. $\mathrm{Dr}=$ diageotropic root.

\begin{tabular}{|c|c|c|c|}
\hline & Parameters Evaluated & fc & $\mathrm{fd}$ \\
\hline \multirow{5}{*}{ Leaflet } & Intercellular spaces of lacunal parenchyma (\%) & $12.59 \mathrm{a}$ & $12.13 \mathrm{a}$ \\
\hline & Diameter of the cells of the superior epidermis $(\mu \mathrm{m})$ & $1.50 \mathrm{a}$ & $0.16 \mathrm{a}$ \\
\hline & Diameter of the cells of the inferior epidermis $(\mu \mathrm{m})$ & $1.30 \mathrm{~b}$ & $0.16 \mathrm{a}$ \\
\hline & Thickness of the leaflet $(\mu \mathrm{m})$ & $7.40 \mathrm{a}$ & $0.68 \mathrm{a}$ \\
\hline & Thickness of the palisade parenchyma $(\mu \mathrm{m})$ & $3.00 \mathrm{a}$ & $0.25 \mathrm{a}$ \\
\hline \multirow{5}{*}{ Root } & Thickness of the lacunal parenchyma $(\mu \mathrm{m})$ & $2.90 \mathrm{a}$ & $0.25 \mathrm{a}$ \\
\hline & Cortical intercellular spaces $(\%)$ & $\mathrm{Sr} 3.11 \mathrm{a}$ & Dr $3,65 \mathrm{a}$ \\
\hline & Diameter of the cortical cells $(\mu \mathrm{m})$ & $8.04 \mathrm{a}$ & $7.67 \mathrm{a}$ \\
\hline & Diameter of the tracheal elements $(\mu \mathrm{m})$ & $1.40 \mathrm{a}$ & $1.60 \mathrm{a}$ \\
\hline & Thickness of the cortical parenchyma $(\mu \mathrm{m})$ & $79.25 \mathrm{a}$ & $92.50 \mathrm{a}$ \\
\hline
\end{tabular}

* Measurements followed by the same letter in columns do not differ by Tukey's test $(\mathrm{P}<0.05 ; \mathrm{n}=5)$.

A

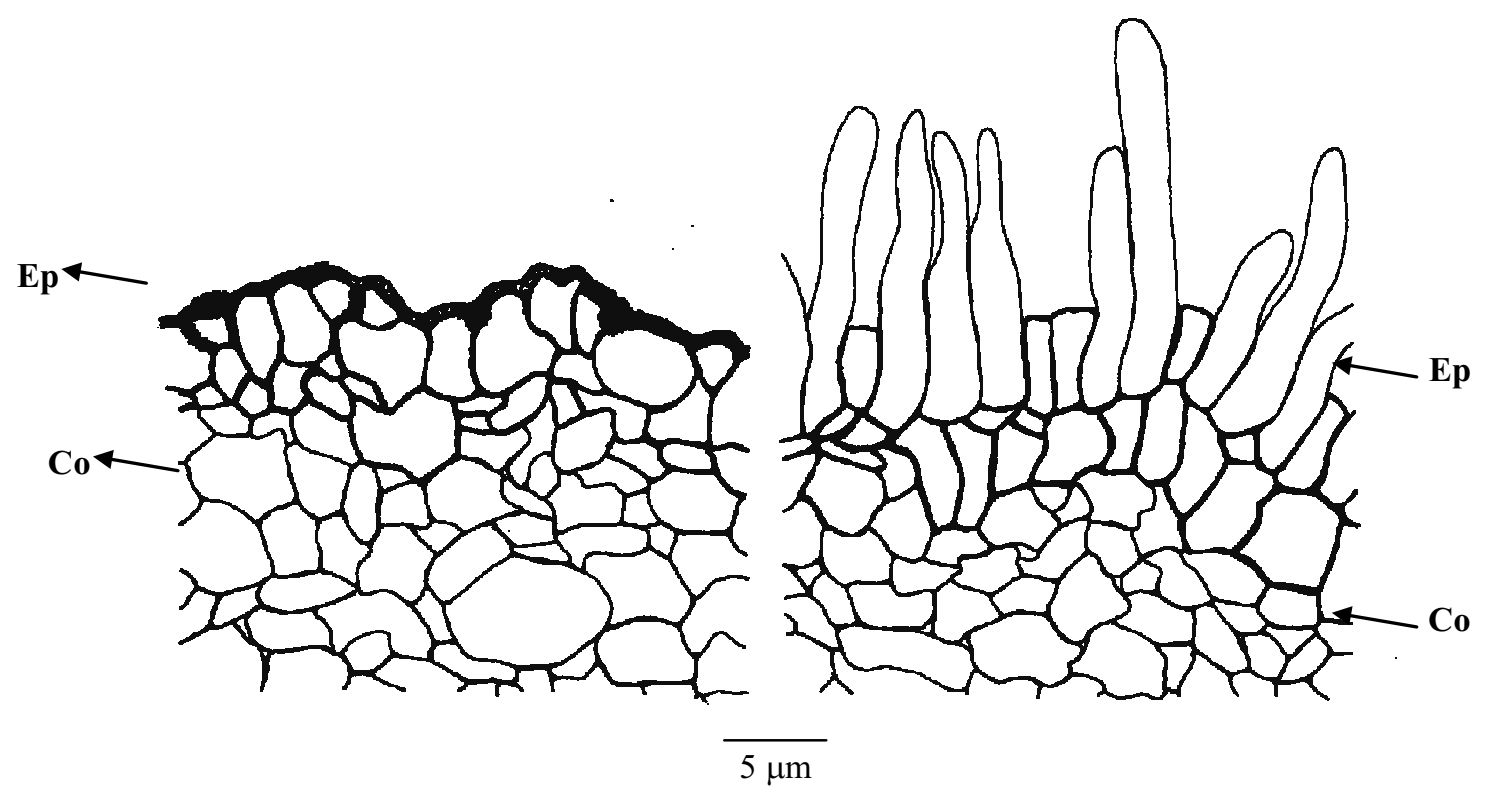

Figure 6 - Anatomic details of transversal cut in secondary root of $T$. avellanedae in field capacity (A) and of diageotropic root in plants flooded for 56 days (B). Ep = epidermis; $\mathrm{Co}=$ cortex. 
This happened together with other factors and interfered in $\mathrm{CO}_{2}$ assimilation. Photosynthesis reduction may be caused by biochemical limitations such as decrease of Rubisco activity (Liao and Lin, 1996). Fall in photosynthesis rate of $T$. avellanedae might be still a consequence of the reduction of nutrient absorption. During inundation a fall in energy levels of the root cells occurs owing to low availability of oxygen for the respiratory metabolism. Maintenance of cell may be interrupted and nutrient acquisition would be impaired (Armstrong et al., 1994). Ascending flow of nutrients may also de reduced during hypoxia because of reduction of transpiration by the stomata closing (Collin-Belgrand et al., 1994).

Downton et al. (1988) suggested that conventional measuring techniques of intercellular $\mathrm{CO}_{2}$ concentration were not adequate to evaluate to which point photosynthesis decrease was due to the stomata closing. Since this technique showed a non-uniform closing of stomata, intercellular $\mathrm{CO}_{2}$ concentration would be overestimated. With more precise methods, cases in which a reduction in photosynthesis was not attributed to stomata closing, could be related to a decrease in stomata conductance. Anyway, more detailed studies were necessary on the photosynthesis properties of the leaf so that suitable conclusions could be reached (Dreyer et al., 1991).

Decrease in photosynthesis and stomata conductance of $T$. avellanedae during flooding were probably responsible for lowering of RGR of leaves and principally of roots. Besides, a certain quantity of photoassimilated factors may have been displaced for the formation of structures, such as diageotropic roots. They con tribute for a lower accumulation of the biomass of the different organs during flooding. Growth decrease in different parts of the plant in terms of the accumulation of dry matter has typically been reported in studies on flooding (Marques et al., 1996; Kolb et al., 1998; Medri et al., 1998). Wiedenroth (1993) and Armstrong et al. (1994) reported that the growth decrease of some organs during flooding could be a strategy to economize energy and keep metabolism of the most affected regions. Thus, the survival of plant was dependent of equilibrium in the distribution of photoassimilated factors among the various parts of the plant. RGR reduction in leaves of $T$. avellanedae may still have been caused by a decrease in nutrient availability. According to
Collin-Belgrand et al. (1991) and Armstrong et al. (1994) this may occur during hypoxia.

While flooding affected photosynthesis, NAR decrease in flooded plants shows a lowering of efficiency of plants as assimilating systems. This might have led to a reduction in their growth. Results in net assimilation similar to those for $T$. avellanedae were also registered by Dreyer et al. (1991) and Pimenta (1998).

Results for the development of $T$. avellanedae showed that species maintained growth of stem in extension during flooding. The roots, however, had pronounced growth impairment. Similarly to what occurs in soils with low oxygen concentration due to flooding, the roots are the first organs affected by hypoxia and generally their growth is greatly impaired (Vartapetian, 1993).

Decrease in the production of new leaves in flooded plants of $T$. avellanedae caused a diminishing of growth in leaf area. Consequently, this resulted in NAR lowering during flooding. Decrease may have also been a consequence of the reduction in nutrient flow towards the aerial part and a redirection of displacement of photoassimilated factors for the production of diageotropic roots. Reduction in leaf production during flooding has also been registered by Pimenta (1998) in Campomanesia xanthocarpa. Increase in the stem's diameter of $T$. avellanedae gave a spongy aspect to the stem at the height of the water lamina. Probably hypertrophy was caused by the formation of aerenchyma. Increase in stem diameter is a typical answer to soil flooding and has been registered by many authors (Pimenta et al., 1994; Lobo and Joly, 1995; Medri et al., 1998). Aerenchyma formed in flooding facilitates internal diffusion of oxygen and allows atmosphere gases to be transported to the submersed parts of the plant (Wiedenroth, 1993). It have been recently verified that in some species stem hypertrophy may have been caused by an increase in exchange activity or by an increase in the number and size of xylem fibers (Yamamoto et al., 1995).

Stem hypertrophy of $T$. avellanedae provoked fissures. Together with hypertrophied lenticels in the roots, this might have been an important factor in the survival of plants during flooding. These fissures, also verified by Joly and Crawford (1982) in Sebastiania klotzchiana and by Davanso-Fabro et al. (1998) in Sesbania virgata, may have the same role of hypertrophied lenticels. According to Hook and Scholtens (1978), the latter would be involved in the 
increase of gas exchange between the atmosphere and the plant.

Another factor that could have an importance in the survival of the species under analysis was the development of diageotropic roots. Growth decrease and death of roots in the deepest layers of soil and the establishment of diageotropic roots may be a strategy in energy economy (Sch lüter et al., 1993). The new roots at the more aired soil surface would be more efficient in $\mathrm{O}_{2}$ transportation and water and ion absorption (Armstrong, 1978). Lobo and Joly (1995) verified that in Talauma ovata flood-induced diageotropic roots had a higher rate of $\mathrm{O}_{2}$ consumption and release of $\mathrm{CO}_{2}$. It shows a more active respiratory metabolism than in other roots. Roots produced during flooding would be also substituting the deteriorated roots during hypoxia in producing vegetal hormones such as cytocynin and gibberellin. The probable hormonal production by diageotropic roots in $T$. avellanedae would avoid early abscission of leaves during flooding. Thus, the survival of plant does not depend on a system of tolerant roots but on the production capacity of ne $\mathrm{w}$ roots substituting the deteriorated ones during flooding (Collin-Belgrand et al., 1991). In their study of hypoxia in T. avellanedae, Messias et al. (1986) verified that species produced many adventitious roots. This has not been registered in the present experiment. Phenotype variation may probably be due to genetic variations among populations of different locals.

Intercellular cortical spaces in $T$. avellanedae in roots and in leaves could be merely constitutive since their formation was not affected by flooding. In their study on species of riparian vegetation with various tolerance degrees, Smirnoff and Crawford (1983) defined as tolerant those species with more than $10 \%$ porosity of roots in drained conditions, while they might or not increase quantity during flooding. Even in some tolerant species, porosity of roots might not react to flooding.

No variation was detected in thickness of root cortex of $T$. avellanedae in flooded plants and those in field capacity. Percentage of intercellular spaces and diameter of cortical cells were equal for both groups. Whereas increase in diameter of cortical cells as a consequence of flooding has been registered in Spathodea campanulata (Medri and Correa, 1985), reduction in diameter of these cells was recorded in Sesbania virgata (DavansoFabro et al., 1998).

The fact that the diageotropic roots of flooded $T$. avellanedae were covered with more hairs than plants in field capacity suggested that an increase in area absorption might be occurring, with greater efficient absorption of water and ions. High concentrations of ethylene may act as stimulator in hair formation in the root of many species such as in the genera Lactuca (Abeles et al., 1992) and Arabidopsis (Dolan et al., 1994). This occurs too in the colon of Chorisia speciosa, since ethylene levels are raised when the plant undergoes flooding (Giloni, personal communication).

If flooded $T$. avellanedae survived during the experiment, possibly owing to their ability in producing photosynthesis, it showed that the species, although not high tolerant to flooding, might adapt itself to short flooding periods. Relative tolerance could be corroborated by ability of $T$. avellanedae to develop the necessary structures to ease flooding effects and thus facilitating the inter nal diffusion of oxygen from the aerial section to the roots. Further, as T. avellanedae did not undergo pronounced variations in leaf and root internal anatomy, metabolic changes probably helped in the survival of species during flooding.

Tolerance of species may vary from a few days to some months and depends on the time of the year, the plant's stage of development, degree and duration of flooding (Crawford and Brändle, 1996). Caution is necessary when verifying the real meaning of tolerance especially in tropical species. Rogge et al. (1998) studied the respiratory metabolism of flooded roots of tolerant and intolerant tropical species. These authors didn't register patterns of answers that would differentiate the two groups. Conclusion confirmed that there was a great variety of mechanisms of flood tolerance. Since the "ipê-roxo" roots were not directly affected by flooding, selection occured in the initial stages of the plant's development. More studies are necessary on the factors that influence its establishment in the field.

\section{ACKNOWLEDGEMENTS}

Present research is part of a project entitled "Aspects of Fauna and Flora in the Tibagi River Basin" supported by the Universidade Estadual de Londrina, Intermunicipal Agreement for Environmental Protection of the Tibagi River Basin, COPATI and KLABIN Fabricadora de Papel e Celulose and FINEP. It had also the support of CAPES and NUPELIA (Research Nucleus in 
Limnology, Ichthyology and Aquiculture) of the Universidade Estadual de Maringá.

\section{RESUMO}

Foram estudadas as modificações morfoanatômicas e ecofisiológicas que o alagamento provoca em Tabebuia avellanedae Lor. ex Griseb. (Bignoniaceae), correlacionando-as com sua capacidade de tolerar o excesso de água no solo. Plantas com três meses de idade, crescendo em casa de vegetação, foram submetidas a 56 dias de alagamento e a um período de pós-alagamento. A taxa fotossintética e o crescimento de $T$. avellanedae decresceram conforme aumentou $\mathrm{o}$ tempo de alagamento, mas mesmo não sendo altamente tolerante, a espécie foi capaz de se adaptar a curtos períodos de alagamento. Esta relativa tolerância provavelmente se deve à capacidade apresentada por $T$. avellanedae de desenvolver estruturas que amenizam os efeitos do alagamento, promovendo a difusão interna de oxigênio da parte aérea para as raízes, tais como rachaduras caulinares, raízes superficiais e lenticelas hipertrofiadas nas raízes. Como não houve acentuada variação na anatomia interna de folhas e raízes de $T$. avellanedae, alterações metabólicas provavelmente auxiliaram na sobrevivência da espécie durante o alagamento.

\section{REFERENCES}

Abeles, F. B.; Morgan, P. W. and Saltveit Jr., M. E. (1992), Ethylene in plant Biology. $2^{\text {nd }}$ ed. Academic Press, San Diego.

Armstrong, W. (1978), Root aeration in the wetland condition. In- Hook, D. D. and Crawford, R. M. M. (eds.). Plant life in anaerobic environments. Ann. Arbor Science, Michigan, pp. 269-298.

Armstrong, W. (1979), Aeration in higher plants. Adv. Bot. Res., 7, 225-332.

Armstrong, W.; Brändle, R. and Jackson, M. B. (1994), Mechanisms of flood tolerance in plants. Acta Bot. Neerl., 43 : (4), 307-358.

Blom, C. W. P. M.; Voesenek, L. A. C. J.; Banga, M.; Engelaar, W. M. H. G.; Rijnders, J. H. G. M.; Steeg, H. M. Van and Visser, E. J. W. (1994), Physiological ecology of riverside species: adaptative responses of plants to submergence. Ann. Bot., 74, 253-263.

Clemens, J.; Kirk, A. M. and Mills, P. D. (1978), The resistence to waterlogging of three Eucaliptus species. Oecol., 34, 125-131.
Colin-Belgrand, M.; Dreyer, E. and Biron, P. (1991), Sensitivity of seedlings from different oak species to waterlogging: effects on root growth and mineral nutrition. Ann. Sci. For., 48, 193-204.

Colli, S. (1998), Aspectos hormonais, anatômicos e do desenvolvimento de duas espécies de Croton submetidas ao alagamento. Tese, Instituto de Biociências, Universidade de São Paulo.

Crawford, R. M. M. (1978), Metabolic adaptation to anoxia. In: Plant life in anaerobic environments, eds. Hook, D. D.; Crawford, R. M. M. Ann Arbor Science, pp. 119-136.

Crawford, R. M. M. and Brändle, R. (1996), Oxygen deprivation stress in a changing environment. J. Exp. Bot., 47 : (295), 145-159.

Davanso-Fabro, V. M., MedriI, M. E.; Bianchini, E. and Pimenta, J. A. (1998), Tolerância à inundação: aspectos da anatomia ecológica e do desenvolvimento de Sesbania virgata (Cav.) Pers. (Fabaceae). Braz. Arch. Biol. Technol., 41 : (4), 475-482.

Dolan, L.; Duckett, C. M.; Grierson, C.; Linstead, P.; Scheneider, K.; Lawson, E.; Dean, C.; Poethig, S. and Roberts, K. (1994), Clonal relatioships and cell patterning in the root epidermis of Arabidopsis. Development, 120, 2465-2474.

Downton, W. J. S.; Loveys, B. R. and Grant, W. J. R. (1988), Non-uniform stomatal closure induced by water stress causes putative non-stomatal inhibition of photosynthesis. New Phytol., 110, 503-509.

Dreyer, E.; Colin-Belgrand, M. and Biron, P. (1991), Photosynthesis and shoot water status of seedlings from different oak species submitted to waterlogging. Ann. Sci. For., 48, 205-214.

Hook, D. D. and Scholtens, J. R. (1978), Adaptations and flood tolerance of tree species. In- Hook, D. D. and Crawford, R. M. M. (eds.). Plant life in anaerobic environments. Ann Arbor Science, pp. 299-331.

Joly, C. A. and Crawford, R. M. M. (1982), Variation on tolerance and metabolic responses to flooding in some tropical trees. J. Exp. Bot., 33, 799-809.

Kolb, R. M.; Medri, M. E.; Bianchini, E.; Pimenta, J. A.; Giloni, P. C. and Correa, G. T. (1998), Anatomia ecológica de Sebastiania commersoniana (Baillon) Smith and Downs (Euphorbiaceae) submetida ao alagamento. Rev. Bras. Bot., 21 : (3), 305-312.

Liao, C. T. and Lin, C. H. (1996), Photosynthetic responses of grafted bitter melon seedlings to flood stress. Env. Exp. Bot., 36, 167-172.

Lima, W. P. (1989), Função hidrológica da mata ciliar. InBarbosa, L. M. (ed.). Simpósio sobre Mata Ciliar. Fundação Cargil, Campinas.

Lobo, P. C. and Joly, C. A. (1995), Mecanismos de tolerância à inundação de plantas de Talauma ovata St. Hil. (Magnoliaceae), uma espécie típica de matas de brejo. Rev. Bras. Bot., 18 : (2), 177-183.

Lorenzi, H. (1992), Árvores brasileiras: manual de identificação e cultivo de plantas arbóreas nativas do Brasil. Plantarum, Nova Odessa, pp. 45. 
Marinho Filho, J. S. and Reis, M. L. (1989), A fauna de mamíferos associada às matas de galeria. In- Barbosa, L. M. (ed.). Simpósio sobre Mata Ciliar. Fundação Cargil, Campinas.

Marques, M. C. M.; Pimenta, J. A. and Colli, S. (1996), Aspectos do metabolismo e da morfologia de Cedrella fissilis Vell. e Anadenanthera colubrina (Vell.) Bren. submetidas a diferentes regimes hídricos. Braz. Arch. Biol. Technol., 39 : (2), 385-392.

Medri, M. E. and Correa, M. A. (1985), Aspectos histológicos e bioquímicos de Joannesia princips e Spathodea campanulata, crescendo em solos na capacidade de campo, encharcado e alagado. Semina, 6 : (3), 147-154.

Medri, M. E.; Bianchini, E.; Pimenta, J. A.; Delgado, M. F. and Correa, G. T. (1998), Aspectos morfoanatômicos e fisiológicos de Peltophorum dubium (Spr.) Taub. submetida ao alagamento e aplicação de ethrel. Rev. Bras. Bot., 21 : (3), 261-267.

Messias, A. M.; Garbe, M.; Bianchini, E. and Medri, M. E. (1986), Aspectos morfológicos, histológicos e bioquímicos de Tabebuia avellanedae Lorentz, crescendo em solos arejado e parcialmente anóxico. InAnais do IV Congresso de Botânica de São Paulo, Universidade Estadual de Campinas.

Pimenta, J. A. (1998), Estudo populacional de Campomanesia xanthocarpa O. Berg (Mytaceae) no Parque Estadual Mata dos Godoy, Londrina-Pr. Tese, Universidade Estadual de Campinas, Instituto de Biologia, Campinas.

Pimentas J. A.; Orsi, M. M. and Medri, M. E. (1994), Aspectos morfológicos e fisiológicos de Coleus blumei Benth. submetido à inundação e à aplicação de ethrel e cobalto. Rev. Bras. Biol., 53 : (4), 427-433.

Reitz, R.; Klein, R. M. and Reis, A. (1978), Projeto madeira de Santa Catarina. Sellowia, 28, 91.

Rogge, G. D.; Pimenta, J. A.; Bianchini, E.; Medri, M. E.; Colli, S. and Alves, L. M. T. (1998), Metabolismo respiratório de raízes de espécies arbóreas tropicais submetidas à inundação. Rev. Bras. Bot., 21 : (2), 153-158.
Ruiz-Sánches, M. C.; Domingo, R.; Morales, D. and Torrecillas, A. (1996), Water relations of fino lemon plants on two rootstocks under flooded conditions. Plant Sci., 120, 119-125.

Schlüter, U. B.; Furch, B. and Joly, C. A. (1993), Physiological and anatomical adaptations by young Astrocaryum jauari Mart. (Araceae) in periodically inundated biotopes of Central Amazonia. Biotropica, 25, 384-396.

Smirnoff, N. and Crawford, R. M. M. (1983), Variation in the structure and response to flooding of root aerenchima in some wetland plants. Ann. Bot., 51, 237-249.

Vartapetian, B. B. (1993), Plant physiological responses to anoxia. Int. Crop Sci., 1, 721-726.

Wiedenroth, E. M. (1993), Responses of roots to hypoxia: their strutural and energy relations with the whole plant. Env. Exp. Bot., 33, 41-51.

Yamamoto, F. and Kozlowski, T. T. (1987), Effects of flooding, tilting of stems, and Ethrel application on growth, stem anatomy and ethylene production of Pinus densiflora seedlings. J. Exp. Bot., 38 : (187), 293-310.

Yamamoto, F.; Sakata, T. and Terazawa, K. (1995), Growth, morphology, stem anatomy, and ethylene production in flooded Alnus japonica seedlings. IAWA J., 16 : (1), 47-59.

Zhang, J. and Davies, W. J. (1987), ABA in roots and leaves of flooded pea plants. J. Exp. Bot., 38, 649-659.

Received: May 02, 2000; Revised: December 17, 2000; Accepted: December 21, 2001. 